\title{
Production and marketing management of groundnut in Vijayapura district
}

\section{SANJAY RATHOD AND C. MURTHY}

Received : 14.07.2017; Revised : 03.09.2017; Accepted : 17.09.2017

\begin{abstract}
Groundnut (Arachis hypogaea L) belongs to the family Fabaceae. Groundnut contains about 26-28 per cent protein and 4850 per cent oil. It is grown during all the season, the major cultivated in Kharif season almost in entire India. Multi-stage random sampling technique was employed to select the 120 sample farmers from Vijayapura district. Among the different categories of farmers, the total variable cost incurred by large farmers was highest (Rs. 27868.01/ha) as compared to small (Rs. 25933.15/ha) and medium farmers (Rs. 25259.77/ha). Among the three categories of farmers, the total cost incurred by the large farmers was highest (Rs. 28804.78/ha) as compared to small and medium farmers (Rs. 26616.99/ha and Rs.26076.92/ha), respectively. The highest yield was obtained by large farmers $(8.26 \mathrm{q} / \mathrm{ha})$ followed by medium farmers $(8.14 \mathrm{q} / \mathrm{ha})$ and small farmers ( $7.83 \mathrm{q} / \mathrm{ha})$. The benefit cost ratio (BCR) was highest in medium farmers (1.82) than small and large farmers (1.77 and 1.73), respectively. The marketing analysis revealed that in respect of groundnut channel-II has more was producer's share in consumers rupee was 82.08 per cent than channel-I was consumer rupee 78.11 per cent.
\end{abstract}

KEY WORDS : Production, Cost and returns, Price spread, Channels, Marketing of groundnut crop

How to cite this paper : Rathod, Sanjay and Murthy, C. (2017). Production and marketing management of groundnut in Vijayapura district. Internat. J. Com. \& Bus. Manage, 10(2) : 179-185, DOI: 10.15740/HAS/IJCBM/10.2/179-185.

\section{MEMBERS OF THE RESEARCH FORUM}

Correspondence to:

C. MURTHY, Department of Agribusiness Management, College of Agriculture, University of Agricultural Sciences, DHARWAD (KARNATAKA) INDIA

Email: cmurthy1966@gmail.com

Authors' affiliations:

SANJAY RATHOD, Department of Agribusiness Management, College of Agriculture, University of Agricultural Sciences, DHARWAD (KARNATAKA) INDIA 